efforts after puerility of style. One was in a popular work on geology, where the beautiful problems of the past of our island and the evolution of life were defaced by the disorderly offspring of a quite megatherial witif one may coin such an antithesis to "etherial." One jest I am afraid I shall never forget. It was a Laocoon struggle with the thought that the huge subsidiary brains in the lumbar region of Stegosaurus suggested the animation of Dr. Busby's arm by the suspicion of a similarly situated brain in the common boy. The second disappointment was a popular lecture professing to deal with the Lick Observatory, and I was naturally anxious to learn a little of the unique appliances and special dis. coveries of this place. But we scarcely got to the Observatory at all. IVe were shown-I presume as being more adapted to our intelligence - numerous lantern-slides of the road to the Lick Observatory, most of them with the "great white dome" in the distance, other views (for comparison probably) with the "great white dome" hidden, portraits of the "gentlemen of the party on horseback," walks round the Observatory, the head of an interesting old man who lived in a cottage near, the dome by moonlight, the dome in winter, and at last the telescope was "too technical" for explanation, and we were told in a superior tone of foolish things our fellow common people had said about it. For my own part, I really saw nothing very foolish in a lady expecting to see houses on the moon. My third experience was ostensibly a lecture on astronomy, but it was really an entertainment-and a very fair one-after the lines of Mr. Grossmith's. "Corney Grain in Infinite Space" might have served as a title. It was very amusing, it was full of humour, but as for science, the facts were mere magazine clicht's that we have grown sick of long ago. And as a pretty example of its scientific value I find a newspaper reporter, whose account is chiefly "(laughter)" with jokes in between, carried away the impression that Herschel discovered Saturn in the reign of George the Third.

Now this kind of thing is not popularising science at all. It is merely making fun of it. It dishonours the goddess we serve. It is a far more difficult thing than is usually imagined, but it is an imperative one, that scientific exponents who wish to be taken seriously should not only be precise and explicit, but also absolutely serious in their style. If it were not a point of discretion it would still be a point of honour.

In another direction those to whom the exposition of science falls might reasonably consider their going more carefully, and that is in the way of construction. Very few books and scientific papers appear to be constructed at all. The author simply wanders about his subject. He selects, let us say, "Badgers and Bats" as the title. It is alliterative, and an unhappy public is supposed to be singularly amenable to alliteration. He writes first of all about Badger A. "We now come," he says, "to Badger B"; then "another interesting species is Badger C"; paragraphs on Badger D follow, and so the pavement is completed. "Let us now turn to the Bats," he says. It would not matter a bit if you cut any section of his book or paper out, or shuffled the sections, or destroyed most or all of them. This is not simply bad art; it is the trick of boredom. A scientific paper for popular reading may and should have an orderly progression and development. Intelligent common people come to scientific books neither for humour, subtlety of style, nor for vulgar wonders of the "millions and millions and millions" type, but for problems to exercise their minds upon. The taste for good inductive reading is very widely diffused ; there is a keen pleasure in seeing a previously unexpected generalisation skilfully developed. The interest should begin at its opening words, and should rise steadily to its conclusion. The fundamental principles of construction that underlie such stories as Poe's
"Murders in the Rue Morgue," or Conan Doyle's "Sherlock Holmes" series, are precisely those that should guide a scientific writer. These stories show that the public delights in the ingenious unravelling of evidence, and Conan Doyle need never stoop to jesting. First the problem, then the gradual piecing together of the solu. tion. They cannot get enough of such matter.

The nature of the problems, too, is worthy of a little attention. Very few scientific specialists differentiate clearly between philosophical and technical interest. To those engaged in research the means become at last almost as important, and even more important than the end, but apart from industrial applications, the final end of all science is to formulate the relationship of phenomena to the thinking man. The systematic reference of Calceola, for instance, Theca, the Lichens, the Polyzoa; or the Termites, is an extremely fascinating question to the student who has just passed the elementary stage, and so too is the discussion of the manufacture and powers of telescopes and microscopes ; morphological questions again become at last as delightful as good chess, and so do mathematical problems. But it must be remembered that morphology, mathematics, and classification are from the wider point of view mere intellectual appliances, and that to the general reader they are only interesting in connection with their end. To the specialist even they would not be interesting if he had not first had their end in view. The fundamental interest of all biological science is the balance and interplay of life, yet for one paper of this type that comes to hand there are a dozen amplified catalogues of the "Cats and Crocodiles" description. I find again, presented as a popular article, a long list of double stars with their chief measurements. Now, to a common man one double star is as good as a feast. Again, the botanist, asked to write about leaves, will get himself voluminously entangled in the discussion whether an anther is a lamina, or in an exhaustive and even exuberant classification of simple and compound, pinnate and palmate, and the like, making great points of the orange leaf and the barberry. But the kind of thing we want to have pointed out to us is why leaves are of such different shapes and so variously arranged. It is a thing all people who are not botanists puzzle over, and a very pretty illustrated paper might be written, and remains still to be written, linking rainfall and other meteorological phenomena, the influence of soil upon root distribution and animal enemies, with this infinite variety of beautiful forms.

Enough has been said to show along what lines the genuine populariser of science goes. Thereare models still in plenty; but if there are models there are awful examples -if anything they seem to be increasing-whoappear bent upon killing the interest that the generation of writers who are now passing the zenith of their fame created, wounding it with clumsy jests, paining it with patronage, and suffocating it under their voluminous and amorphous emissions. There is, I believe, no critical literature dealing generally with the literary merits of popular scientific books, and there are no canons for such criticism. It is, I am convinced, a matter that is wortiny of more attention from scientific men, if only on the grounds mentioned in my opening paragraphs.

\section{H. G. IVELLS.}

\section{ON THE NEIV BUILDINGS FOR THE ST} ANDREWS (GATTY) MARINE LABORATORY.

\section{THAT St. Andrews had not one of the oldest marine}

laboratories was the result of an accident. Nevertheless it has the oldest marine laboratory in Britain, since it was opened early in 1884 , though since 1882 the practical laboratory in the College had been used for this purpose; and it could not well be otherwise, since it was No. I. 29 I, voI. 50] 
within a stone's cast of the bay-so rich in a varied fauna and flora. For ten years the work of the laboratory has been carried on under considerable difficulties in a wooden building originally erected as a temporary feverhospital, and the walls and roof of which were neither wind- nor water-tight. This structure was situated on a spit of sand near the harbour, and most conveniently placed for easy access to the fishing-boats and the beach; but it was on a public common, and though for nearly two years every effort has been made to get the new laboratory erected on the same site, it was found to be impracticable, and a new site was therefore chosen on University ground, about 300 yards further south, and close to the beach. This site affords ample space, and, besides, a small fresh-water stream flows through it.

The new laboratory is the munificent gift of Dr. Charles Henry Gatty, of Felbridge Place, East Grinstead, who has placed $£ 2500$ at the disposal of the University of St. Andrews for its erection. The building will face the west, with the back towards the east and the sea, and will be for the most part of one storey. From its eastern or sea face the windows command an extensive view of the picturesque bay, with the Forfarshire coast terminating mirror, and other fittings, on the right wall a series of shelves (P) for books and other things, while belind is a cabinet of drawers (o) for storage of delicate apparatus and specimens. From the position of the building three of these windows look to the sea, and three to the west ; while a seventh admits light from the southern end of the building. In the centre of the room is a series of tanks of sea-water, six in number (one for each worker), besides various shelves for smaller glass aquaria, and the necessary pipes and nozzles for distributing sea-water as required. A fireproof compartment for long-continued use (all night) of the hot bath occurs at one end, while each worker has a separate small paraffin apparatus in his compartment.

The lobby on the left leads to the tank-room ( $J$ ) or aquarium, $30 \mathrm{ft} .6 \mathrm{in}, \times 30 \mathrm{ft}$., and with three windows on each side (east and west) for illuminating the tanks-of slate and glass-ranged round the room, as well as placed in the centre. While that part of the building already described has wooden floors, the aquarium is paved with concrete. A door at the northern end leads by a few steps to the receiving-room (k), with its long table and sink, where the specimens procured by the

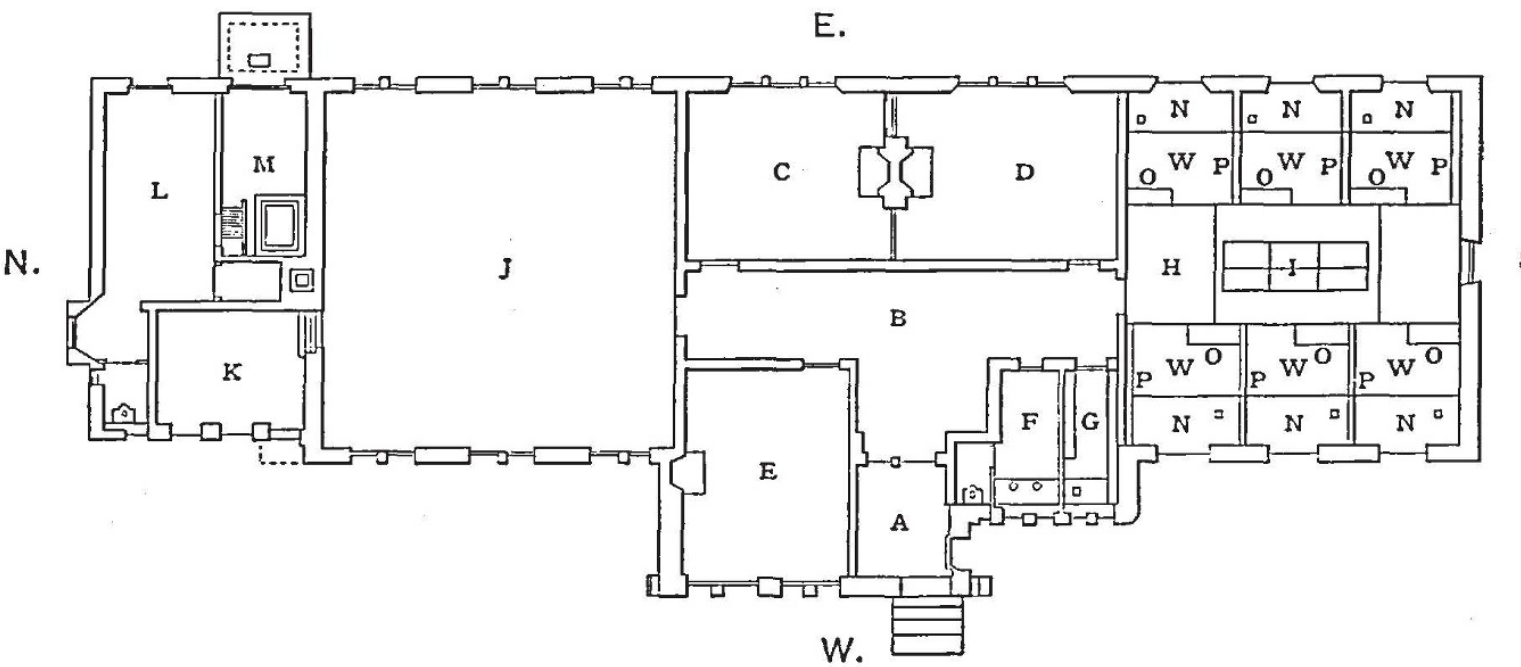

S.

A, Vestibule ; B. Hall ; c, Director's Room; D, Library ; E, Room for Specimens ; F, Cloak Room and Lavatory : G, Chemical Room ; u, Research Room; I, Tanks of Room; w, Workers' Compartments; o, Workers' Cabinets; p, Workers' Bookshelves; J, Tank Room; k, Receiving Room; L, Engine and Pumps; $s$, Heating Chamber.

in the steep rocks of the "Red Head" on the left, and on the right the well-known cliffs from which the "Rock and Spindle "and "Maiden Rock" standout boldly, while here and there a more gentle slope gives a patch of bright green sward. The western face or front has a view embracing the fine old ruins of the cathedral, the southern suburbs of the city, and a wide stretch of Fife, including such eminences as Drumcarro Craig and Clatto Hill. It has a frontage of 125 feet, and the building is in the Scottish style of architecture-unpretending externally, but comfortab!e and convenient internally.

The entrance is in the projecting block on the west, leading into a vestibule (A), and a spacious hall (B), with lobbies leading right and left. In this blnck are situated three official rooms, viz. the Director's room (c), the library (D), and the room for specimens (E), the two former looking into the bay, the latter to the west. Besides these are a cloak-room with lavatory $(F)$ and a chemical room (G). The lobby on the right leads to the research room $(\mathrm{H})$, which is $30 \frac{1}{2} \mathrm{ft} . \times 30 \mathrm{ft}$., and contains compartments (w) Io ft. square, with partial partitions about $\delta \mathrm{ft}$. in height, for six workers. Each of these has at the window a large and convenient table (N) with sink, boats are arranged by the attendant before being introduced into the tank-room or distributed to the workers. The outer door to this room is on the western face of the building (front), and above it is a large storage-tank for sea-water. In this block are the apartments for the engine and pumps (L), a store and the heating-chamber with accessories (MI), all these being entirely separated from the tank-room by a thick wall of stone.

The main apartments are heated by hot-water pipes, with the exception of the three in the centre (viz. Directors' room, library, and museum), which have fireplaces for gas.

The laboratory is capable of easy extension should that ever be necessary, and it is readily reached from the class-rooms of the University. Moreover, being in direct connection with the latter, the workers have the advantage of free access to the University library and museum, besides that communication with those of similar tastes, which is so congenial as well as profitable to the naturalist, and which cannot be compensated by mere richness of fauna and flora, if these are in an isolated locality or difficult of access.

Further, in addition to its connection with the Univer-

NO. I 29 I, vOL. 50] 
sity, the laboratory from the first has been under the control of the Fishery Board for Scotland, who administered the Parliamentary grant given in 1884 for its equipment, and who maintain the attendant and defray certain other expenses.

Ample space exists for the formation of large external ponds and tanks, and certain portions of the tidal rocks in the neighbourhood are fitted for enclosure, so that young fishes and crustaceans may be reared from the post-larval stages onward, under conditions as closely approaching nature as possible. In the same way the culture of useful mollusks can be experimented with.

The beach at St. Andrews is remarkably adapted for marine researches, since it combines extensive reaches of sand with their special forms, and on which a vast variety of materials in a fresh state are stranded by storms, with great stretches of tidal rocks and rock-pools so rich in littoral animals and plants. The valuable mussel-bed in the estuary of the Eden, the proximity of the Forth and the Tay, the constant stream of specimens brought by the fishing-boats, and the plenitude of life in the bay itself-all combine to render it classic ground to the naturalist. For example, amongst the rarer forms at St. Andrews are Corymorpha, Cerianthus, Pennatula, Asterias Miilleri, Echiurus, Magelona, Tornaria Mitraria, swarms of Appendicularians (Oikopleura), Pelonaia, Actinotrocha, the Pteropods Clione and Spirialis, the Nudibranch Idalia, and the Tectibranch Aplysia.

The greatly improved facilities for research which the munificence of Dr. Gatty has granted to St. Andrews cannot but increase the results in regard to marine biological science and the fisheries, and render the old University city even better known in this connection in the future than in the past. Yet there are those still living who remember the glee of Edivard Forbes as he picked up the living spoon-worms (Echiuri) on the west sands, and who listened to a short course of lectures he gave in the University on star-fishes, before the publication of his work on this group, and who were familar with the figure of John Reid as he descended the steps at the Baths to hunt for Hydra tuba, and watch the scyphistomastage of Aurelia, which he independently worked out there. It is unnecessary on the present occasion to allude to the names of more recent workers, but they are many, and include continental and American, as well as those of our own country.

W. C. M.

\section{NOTES.}

ALL who take an interest in science will be glad to hear that the health of Prof. von Helmholtz has been improving of late, and that he has regained partial use of his paralysed side.

THE resignation of Prof. Dana, from the position he has so long occupied at Yale University, is announced. Dr. Dana was appointed, in 1850 , Silliman Professor of Natural History and Geology at Yale, and now at the age of eighty-one years he is compelled to abandon further active work by reason of feeble health. We hope that many years of well-earned rest remain to him.

Prof. HI. S. Williams, formerly of Cornell University, has been appointed Prof. Dana's successor at Yale University.

THE sixty-second annual meeting of the British Medical Association will take place at Bristol, from July $3 \mathbf{I}$ to August 3 , under the presidency of Dr. E. Long Fox. The report which the council has to present is, we understand, a very favourable one, and shows that the membership of the Association has increased from 14,703 to 15,090 , and the total investments to $£_{4} \mathbf{r}, 789$. Dr. Long Fox is to deliver his address on Tuesday, July $3 \mathbf{I}$, and during the meeting the following addresses will be delivered :-On Medicine, by Prof. Sir T.
Grainger Stewart; on Surgery, by Prof. Greig Smith; and on Public Medicine, by Sir Charles Cameron.

THE Société Industrielle de Mulhouse has issued a programme of the prizes to be awarded next year. The prizes are open to all, whether natives of France or not, and works competing for them must reach the President of the Society before February 15, 1895. Most of the awards consist of medals only, but some carry with them prizes varying from one hundred to five thousand francs. A complete programme can be obtained by applying to the Secretary of the Society, MIulhouse.

TiIE twenty-third meeting of the French Association for the Advancement of Science will be opened at Caen on August 9, under the presidency of Prof. Mascart. The work of the Association will be divided into four groups, each containing from three to five sections. The first group (Sciences Mathé. matiques) will be devoted to mathematics, astronomy, and geodesy, mechanics, navigation, civil and military engineering. To Group II. (Sciences Physiques et Chimiques) belong physics, chemistry, meteorology, and terrestrial physics. In the third group (Sciences Naturelles et Médicales) will be found geology and mineralogy, botany, zoology, anatomy, physiology, anthropology, and medical sciences. The fourth group (Sciences Économiques) is concerned with agriculture, geography, political economy and statistics, pedagogy, hygiene, and public health.

THE next annual meeting of the Italian Botanical Society will take place at Palermo, in 1895 . For the present year a botanical excursion is arranged, on September 25 and the three following days, to the Island of Giglio, the largest of the Tuscan Archipelago, except Elba, the flora of which has been but imperfectly explored. Botanists desirous of taking part in the expedition should communicate, not later than September 15, with the President, Prof. Arcangeli, 19 Via Romana, Florence.

INFORBIATION has come to hand respecting an International Exhibition of Arts, Industries, \&c., which is to be held at Bordeaux in 1895 . The exhibition, which is the thirleenth held at Bordeaux, will be opened on May $\mathrm{r}$, and will be divided into some ten Sections, as follows:-Section I. Education. II. Arts (Liberal, Industrial, and Decorative; Medicine, Hygiene, \&c.). III. Social Sciences. IV. Agriculture, Horticulture. V. IVines and Spirits. VI. Industries (Mineralogical, Mechanical, Chemical, \&c.). VII. Habitation (Furniture, Dress, \&c.). VIII. Transport, Civil Engineering, and Military Art. IX. Electricity. X. Cormerce and Colonies. England, Belgium, Italy, Portugal, Spain, and Switzerland are invited to contribute.

THE seventeenth annual meeting of the Midland Union of Natural History and Scientific Societies will take place on August 3 and 4 , at Ellesmere, under the auspices of the Ellesmere Natural History Society and Field Club. A strong programme has been arranged, and after the business meetings of August 3 a conversazione will be held at St. Oswald's College. The following day will be taken up by three excursions : one to Chirk, Llangollen, and Valle Crucis for the archæologists, led by Mr. A. T. Jebb; a second, round the Meres and Peat Mosses of the neighbourhood for the biologists, under the leadership of Messrs. Peake, Jennings, and Thompson. The third, for the geologists, will be under the guidance of Dr. Callaway, who will conduct his party to Hawkstone and Grinshill. IVe understand that the Ellesmere Society hope that many of the visitors will be able to stay in the neighbourhood over the Bankholiday, when further excursions may be arranged, and they are perfecting the arrangements in a most generous and hospitable spirit.

WE hear, with much regret, of the death, at the age of seventy-nine years, of Dr. Daniel Cornelius Danielssen, who NO. I 291, VOL. 50] 